\title{
A New Bromite Oscillator. Large-Amplitude pH Oscillations in the Bromite-Thiosulfate-Phenol Flow System ${ }^{1}$
}

\author{
Miklós Orbán ${ }^{2}$ and Irving R. Epstein*,3 \\ Institute for Inorganic and Analytical Chemistry, L. Eötvös University, P.O. Box 32, Budapest 112, Hungary, \\ and Department of Chemistry, Brandeis University, Waltham, Massachusetts 02254-9110
}

Received: October 12, 1994; In Final Form: December 8, $1994^{\otimes}$

\begin{abstract}
The reaction between bromite and thiosulfate ions in aqueous solution with and without phenol has been studied under batch and flow conditions. The bromite oxidation of thiosulfate proceeds via two consecutive fast reactions, the first accompanied by a significant increase, the second by a large decrease in $\mathrm{pH}$. The $\mathrm{H}^{+}$ production is autocatalytic and strongly influenced by phenol. The bromite-thiosulfate-phenol flow system exhibits bistability and large-amplitude $\mathrm{pH}$ oscillations. Several relevant reactions such as bromite-phenol, bromite-bromide, bromate-thiosulfate, and bromate-phenol were also investigated, and their participation in the batch and flow behavior of the bromite-thiosulfate-phenol system is discussed. A qualitative explanation of the $\mathrm{pH}$ oscillation is proposed.
\end{abstract}

\section{Introduction}

Reaction systems based on the chemistry of the bromite ion represent the most recently discovered family of chemical oscillators. Within the past 2 years, the bromite-iodide ${ }^{4}$ and the phenol-perturbed bromite-hydroxylamine ${ }^{5}$ flow systems have been found to be bistable and to exhibit sustained oscillation.

In this paper, we describe and characterize a third member of the family of bromite oscillators. In a continuously fed stirred tank reactor (CSTR), at an appropriately chosen set of input concentrations and flow rates, the reaction between bromite and thiosulfate ions in the presence of phenol shows bistability and oscillations in the $\mathrm{pH}$ and in the potential of a $\mathrm{Pt}$ electrode. The study of oscillatory bromite systems is of interest not only from a dynamical point of view but also because it adds to our knowledge of the properties and reactions of the relatively obscure chemistry of the bromite ion.

\section{Experimental Section}

Materials. The major reagents used in this work were $\mathrm{NaBrO}_{2} \cdot 3 \mathrm{H}_{2} \mathrm{O}$ (Aldrich, technical grade), $\mathrm{NaBrO}_{3}$ (Fisher, certified), $\mathrm{Na}_{2} \mathrm{~S}_{2} \mathrm{O}_{3} \cdot 5 \mathrm{H}_{2} \mathrm{O}$ (Fisher, certified), and phenol (Mallinckrodt, $100 \%$ ). Stock solutions of $10^{-2}-10^{-3} \mathrm{M}$ concentration were prepared by dissolving the appropriate solid in distilled water. The bromite and thiosulfate stock solutions were standardized by iodometric titration. Concentrations of bromate and phenol solutions were calculated from the weight of the solid.

For preparing bromite stock solutions, we used a 2-year-old supply of $\mathrm{NaBrO}_{2} \cdot 3 \mathrm{H}_{2} \mathrm{O}$ purchased from Aldrich. Unfortunately, both Aldrich and Merck, which supplied the bromite earlier, stopped its distribution in 1992. In spite of having been tightly sealed and refrigerated, the solid bromite had partially decomposed during storage. The major decomposition product is $\mathrm{NaBrO}_{3}$. The bromite and bromate contents were determined iodometrically as follows. In a $\mathrm{CH}_{3} \mathrm{COOH}-\mathrm{CH}_{3} \mathrm{COONa}$ buffer of $\mathrm{pH} 4.7$, only the bromite oxidizes iodide to iodine. After the iodine was measured with standard thiosulfate solution, the reaction mixture was acidified to $\mathrm{pH} \sim 0$ and the iodine liberated by reaction with the $\mathrm{BrO}_{3}{ }^{-}$was again titrated. The $\mathrm{NaBrO}_{2} \cdot 3 \mathrm{H}_{2} \mathrm{O}$

${ }^{\otimes}$ Abstract published in Advance ACS Abstracts, February 1, 1995. content of our sample was found to be $68.1 \%$. The $\mathrm{NaBrO}_{3}$ in the sample was $14.0 \%$. The solid $\mathrm{NaBrO}_{2} \cdot 3 \mathrm{H}_{2} \mathrm{O}$ contained about $15-16 \%$ hygroscopic water. According to the literature, ${ }^{6}$ sodium bromite may be contaminated with $\mathrm{NaOBr}$ and $\mathrm{NaBr}$ as well. We found neither $\mathrm{NaOBr}$ nor $\mathrm{NaBr}$ in our sample. The presence of $\mathrm{NaOBr}$ was ruled out by using the method suggested by Lee and Lister. ${ }^{7}$ The absorption spectrum of the aqueous bromite solution was taken, and the maxima at 296 and $330 \mathrm{~nm}$, characteristic of bromite and hypobromite, respectively, were compared. The ratio found, 1.36, agrees with the literature value for a hypobromite-free sample. The stock solution of bromite was always freshly prepared and consumed within $5 \mathrm{~h}$.

Apparatus and Methods. The batch reaction between bromite and thiosulfate in the absence and presence of phenol was followed by measuring the change in $\mathrm{pH}$ (Orion $\mathrm{pH}$ meter, Aldrich combined glass $\mathrm{pH}$ electrode) and the potential of a $\mathrm{Pt}$ electrode (Radiometer $\mathrm{P} 101$ ) vs $\mathrm{Hg}\left|\mathrm{Hg}_{2} \mathrm{SO}_{4}\right| \mathrm{K}_{2} \mathrm{SO}_{4}$ reference electrode (Radiometer K601). The same experimental arrangement was used for monitoring the course of the reaction between bromate and thiosulfate, bromite and bromide, and bromite and phenol. Additional data on the bromite-phenol reaction were obtained from the absorption spectra taken with a HewlettPackard 8452A diode array spectrophotometer and from measuring the bromite consumption by iodometric titration.

The flow experiments were performed in a $20.5-\mathrm{cm}^{3}$ thermostated reactor equipped with $\mathrm{pH}, \mathrm{Pt}$, and reference electrodes. A four-channel peristaltic pump (Sage Instruments, Model $375 \mathrm{~A}$ ) was used to feed the input solutions into the reactor. The effluent was removed by overflow with aspiration. The flow rate could be varied continuously between $6 \times 10^{-4}$ and $1 \times 10^{-2} \mathrm{~s}^{-1}$. The dynamical states of the system were determined by measuring the responses of the $\mathrm{pH}$ and $\mathrm{Pt}$ electrodes as functions of the input concentrations and flow rate. All experiments were carried out at a constant temperature of $25 \pm 0.1{ }^{\circ} \mathrm{C}$.

\section{Results}

The Problem of Bromate Interference. Because of decomposition during storage, the $\mathrm{NaBrO}_{2}$ always contains bromate impurities, which may comprise a few percent to the entire sample, depending on the time and temperature of storage and 


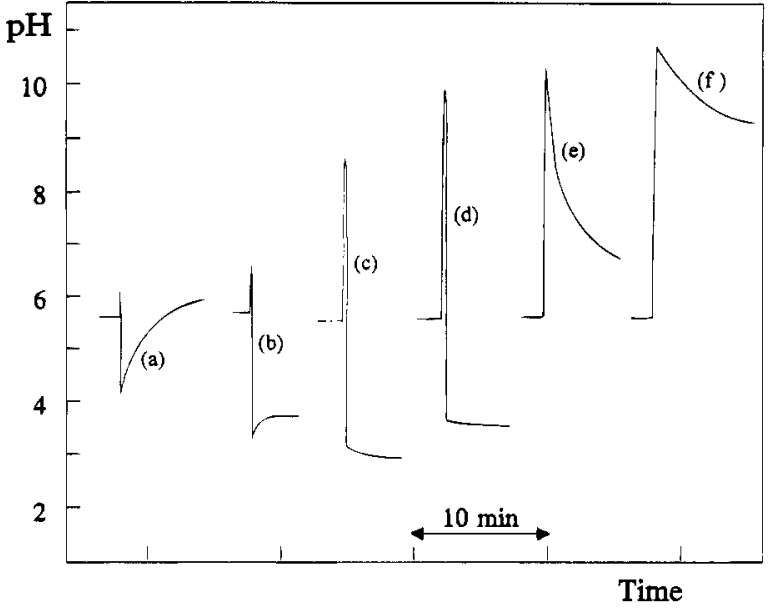

Figure 1. Time evolution of the $\mathrm{pH}$ in the bromite-thiosulfate batch reaction. In all curves, $\left[\mathrm{BrO}_{2}^{-}\right]=2.5 \times 10^{-3} \mathrm{M}$. $\left[\mathrm{S}_{2} \mathrm{O}_{3}{ }^{2-}\right]=2 \times$ $10^{-4} \mathrm{M}(\mathrm{a}) ; 4 \times 10^{-4} \mathrm{M}$ (b); $1 \times 10^{-3} \mathrm{M}$ (c); $2 \times 10^{-3} \mathrm{M}$ (d); $5 \times$ $10^{-3} \mathrm{M}(\mathrm{e}) ; 1 \times 10^{-2} \mathrm{M}(\mathrm{f})$.

on the frequency of opening the container. Like bromite, the bromate ion is a strong oxidant. Therefore, in studying the reactions of bromite, one must consider the possibility of parallel bromate reactions.

Since oscillations and bistability in the bromite-thiosulfatephenol flow system occur between $\mathrm{pH} 3$ and 8 , we studied the reactions of bromate with thiosulfate and phenol in this $\mathrm{pH}$ range. Our batch experiments on the $\mathrm{BrO}_{3}{ }^{-}-\mathrm{S}_{2} \mathrm{O}_{3}{ }^{-}$and the $\mathrm{BrO}_{3}{ }^{-}$-phenol systems yield the following conclusions: (i) No reaction occurs between bromate and phenol at $\mathrm{pH}>3 .^{8}$ (ii) Bromate and thiosulfate react slowly under these conditions. Depending on the initial concentration ratio of bromate to thiosulfate, processes can occur that either increase or decrease the $\mathrm{pH}$. Sorum et al. ${ }^{9}$ report similar observations in experiments at various initial $\mathrm{pH}$ 's on solutions containing $0.06 \mathrm{~N} \mathrm{KBrO}_{3}$ and $0.05 \mathrm{~N} \mathrm{Na}_{2} \mathrm{~S}_{2} \mathrm{O}_{3}$. Their $\mathrm{pH}$-time curves suggest, as do ours, a complex reaction that can be fast at low $\mathrm{pH}$. At $\mathrm{pH}>$ 4 and reactant concentrations that give rise to oscillations (about an order of magnitude lower than in ref 9), however, the reaction is so sluggish that no significant interference from bromate should occur in the bromite-thiosulfate reaction in a CSTR at pH 4-8.

Batch Experiments. As we show below, the bromitethiosulfate-phenol system exhibits oscillations in $\mathrm{pH}$ and bistability between a high-pH and a low-pH steady state when the reaction is performed in a CSTR. In order to elucidate the underlying chemistry, we monitored the $\mathrm{pH}$ and the potential of a $\mathrm{Pt}$ electrode in batch experiments with concentrations similar to those at which the oscillations and the bistability occur.

(1) The Bromite-Thiosulfate Reaction in the Absence and Presence of Phenol. Figure 1 shows the time evolution of the $\mathrm{pH}$ at different ratios of bromite to thiosulfate. Curves $\mathrm{a}-\mathrm{f}$ indicate two fast steps during which the $\mathrm{pH}$ first increases and then drops.

In Figure 2, we show curve $d$ of Figure 1 at a 10 -fold faster chart speed. The $\mathrm{pH}$ rise still appears to be instantaneous, while the $\mathrm{pH}$ decrease, which is now resolvable, suggests an autocatalytic production of $\mathrm{H}^{+}$. The fast $\mathrm{pH}$ rise and the much slower $\mathrm{S}$-shaped $\mathrm{pH}$ drop become more clearly separated in time if the bromite-thiosulfate ratio is maintained and both concentrations are lowered.

The effect of phenol on the batch reaction between bromite and thiosulfate at the composition of Figure 1, curve d, is shown in Figure 3. The $\mathrm{pH}$ increase is barely affected by the presence

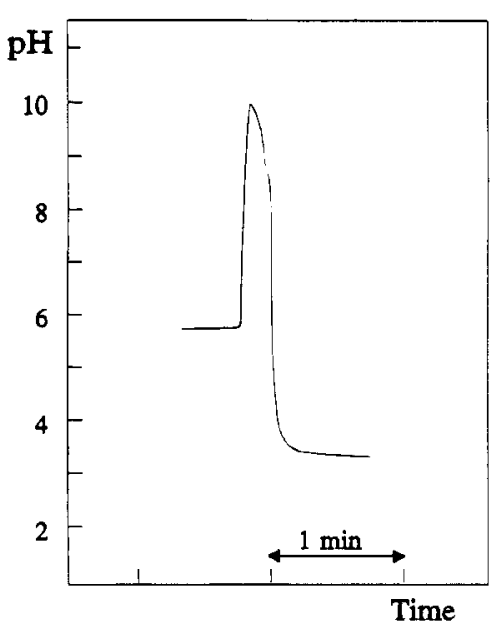

Figure 2. $\mathrm{pH}$ evolution in curve $\mathrm{d}$ of Figure 1 shown on an expanded time scale.

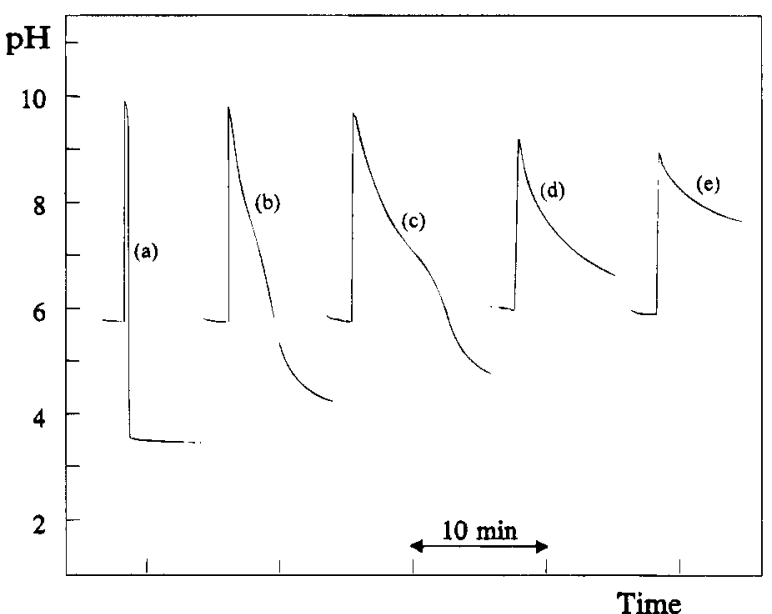

Figure 3. Effect of phenol on the bromite-thiosulfate batch reaction. Concentrations of bromite and thiosulfate and temperature are as in curve d of Figure 1. [Phenol] $=0$ (a); $5 \times 10^{-4} \mathrm{M}(\mathrm{b}) ; 1 \times 10^{-3} \mathrm{M}$ (c); $3 \times 10^{-3} \mathrm{M}(\mathrm{d}) ; 5 \times 10^{-3} \mathrm{M}(\mathrm{e})$.

of phenol, but the $\mathrm{H}^{+}$production is slowed significantly and even disappears at higher phenol concentrations.

(2) The Reaction between Bromite and Phenol. We were unable to find any study in the literature of the reaction between bromite and phenol. All our batch experiments were performed under the conditions at which oscillations with thiosulfate were observed. Mixing of bromite and phenol resulted in an increase in $\mathrm{pH}$. When $5 \times 10^{-3} \mathrm{M}$ phenol was added to $2.5 \times 10^{-3} \mathrm{M}$ bromite, the $\mathrm{pH}$ of the solution dropped from about 10.2 (the $\mathrm{pH}$ of a freshly prepared $2.5 \times 10^{-3} \mathrm{M}$ bromite solution) to 8.2 , then slowly increased to about 9 as a pale pink color, similar to that seen in some old discolored solid phenol samples, developed. If the $\mathrm{pH}$ of the bromite solution was initially adjusted to 6 , the mixture reached a final $\mathrm{pH}$ of 8.5 after about an hour. We followed the decrease in the bromite concentration after addition of phenol by iodometric titration. In a mixture of $5 \times 10^{-3} \mathrm{M}$ phenol and $4.5 \times 10^{-3} \mathrm{M}$ bromite, the concentration of bromite decreased to $3.2 \times 10^{-3}, 2.7 \times 10^{-3}$, and $1.5 \times 10^{-3} \mathrm{M}$ after 15,30 , and $60 \mathrm{~min}$, respectively, and a deep pink color appeared.

To identify the products of the bromite-phenol reaction, we took absorption spectra in the wavelength range $250-500 \mathrm{~nm}$ with a diode array spectrophotometer. We illustrate our results by discussing the time evolution of spectra recorded at 10 -min intervals for $150 \mathrm{~min}$ in a mixture initially containing $1.0 \times$ $10^{-3} \mathrm{M}$ phenol and $4.5 \times 10^{-3} \mathrm{M}$ bromite. The absorption maxima for phenol and bromite are at 270 and $296 \mathrm{~nm}$, 
respectively. ${ }^{10.11}$ The $\mathrm{pH}$ of the reaction mixture was initially 8.7 ; it rose to 9.3 by the end of our observation period. A new maximum at $299 \mathrm{~nm}$, characteristic of $p$-bromophenol in alkaline environment, ${ }^{12}$ began to develop immediately after mixing. The absorption peaks of phenol and bromite simultaneously began to decrease. Analysis of the spectra showed that after $45 \mathrm{~min}$ $50 \%$ of the initial phenol had been converted to $p$-bromophenol. The yield was $90 \%$ after $130 \mathrm{~min}$. From the [ $p$-bromophenol] vs time curve, we calculated the initial rate and obtained a second-order rate constant for the bromite-phenol reaction at $\mathrm{pH} 8.7-9.3$ of $4.5 \times 10^{-2} \mathrm{M}^{-1} \mathrm{~s}^{-1}$. We failed to assign the pink color (absorption maximum at $490 \mathrm{~nm}$ ) to any reaction product. On the other hand, no pink color was observed in any of our batch or flow experiments in which thiosulfate was present. It is unclear whether this side reaction plays any role in the oscillatory process. However, because the oscillatory behavior in the title reaction is quite sensitive to the input bromite concentration, the reaction of bromite and phenol to yield $p$-bromophenol is a likely participant in the oscillatory cycle.

(3) The Reaction between Bromite and Bromide. We repeated some of the batch reactions reported by Massagli et al., ${ }^{6}$ who demonstrated that at $\mathrm{pH} \sim 7$ bromide ions react very slowly with bromite. From Massagli et al.'s and our results, we have concluded that (i) it is highly improbable that a "minimal bromite oscillator" in which the $\mathrm{BrO}_{2}{ }^{-}-\mathrm{Br}^{-}$reaction would represent the overall stoichiometry is possible and (ii) bromide inhibition, which plays a key role in the oscillatory bromate systems, has no importance in the bromite oscillators.

Flow Experiments. The reaction between bromite and thiosulfate was run in a CSTR both in the absence and the presence of phenol at a series of flow rates $\left(k_{0}\right)$. In the absence of phenol, only a single steady state with $\mathrm{pH}$ between 3 and 9 was observed at each composition and flow rate in the bromitethiosulfate flow system. Under certain experimental conditions, this steady state can be destabilized by introducing phenol, leading to bistability and oscillations.

Bistability, for example, is observed if the composition shown in Figure 1, curve c, is introduced into the CSTR together with an appropriate amount of phenol. With $\left[\mathrm{BrO}_{2}^{-}\right]_{0}=2.5 \times 10^{-3}$ $\mathrm{M}$ and $\left[\mathrm{S}_{2} \mathrm{O}_{3}{ }^{2-}\right]_{0}=1 \times 10^{-3} \mathrm{M}$ (the subscript zero denotes the concentration in the reactor if no reaction were taking place), two steady states are found at each flow rate within the bistable range $\left(\Delta k_{0}\right)$ if $[\text { phenol }]_{0}=5 \times 10^{-4}-7.5 \times 10^{-4} \mathrm{M}$. One steady state (SSI, flow branch) is characterized by a high $\mathrm{pH}(7.4-9)$ and occurs if $\Delta k_{0}$ is approached from the high $k_{0}$ side. The other steady state (SSII, thermodynamic branch) exhibits a low $\mathrm{pH}(\sim 3)$ and is reached if $\Delta k_{0}$ is approached from below. When $[\text { phenol }]_{0}<5 \times 10^{-4} \mathrm{M}$, only SSII occurs. When [phenol] $]_{0} \geq$ $1 \times 10^{-3} \mathrm{M}$, only SSI exists. In the bistable region between [phenol $]_{0}=5 \times 10^{-4} \mathrm{M}$ and $7.5 \times 10^{-4} \mathrm{M}$, the $\Delta k_{0}$ range starts from $k_{0}=4 \times 10^{-3} \mathrm{~s}^{-1}$ and $k_{0}=1 \times 10^{-3} \mathrm{~s}^{-1}$, respectively, and continues to at least $k_{0}=1.5 \times 10^{-2} \mathrm{~s}^{-1}$, the highest flow rate attainable with our pump. Transitions between SSI and SSII can be induced by perturbing the bistable system with dilute acid or base. It is interesting to note that at some compositions of the bromite-thiosulfate-phenol flow system the steady-state $\mathrm{pH}$ decreases on the introduction of $\mathrm{NaOH}$ solution. This inverse regulation by $\mathrm{OH}^{-}$indicates that addition of $\mathrm{NaOH}$ can promote the bromite oxidation of thiosulfate to sulfuric acid, forming more than enough acid to neutralize the added base.

Bistability, though neither necessary nor sufficient for oscillation, is often found in chemical systems that show oscillatory behavior under other experimental conditions. In the bromitethiosulfate-phenol mixture, we found oscillations in the $\mathrm{pH}$

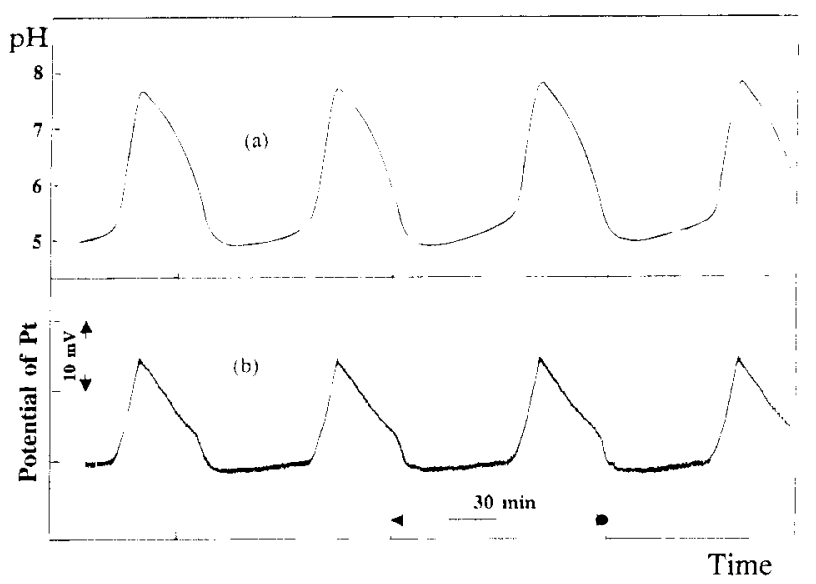

Figure 4. Oscillations in the bromite-thiosulfate-phenol-sodium hydroxide flow system. $\left[\mathrm{BrO}_{2}{ }^{-}\right]_{0}=2.5 \times 10^{-3} \mathrm{M},\left[\mathrm{S}_{2} \mathrm{O}_{3}{ }^{2-}\right]_{0}=2.0 \times$ $10^{-3} \mathrm{M}$, [phenol $]_{0}=5.0 \times 10^{-3} \mathrm{M},[\mathrm{NaOH}]_{0}=5.0 \times 10^{-4} \mathrm{M}$. Flow rate $k_{0}=8 \times 10^{-4} \mathrm{~s}^{-1}(\mathrm{a}) ; 1.2 \times 10^{-3} \mathrm{~s}^{-1}$ (b).
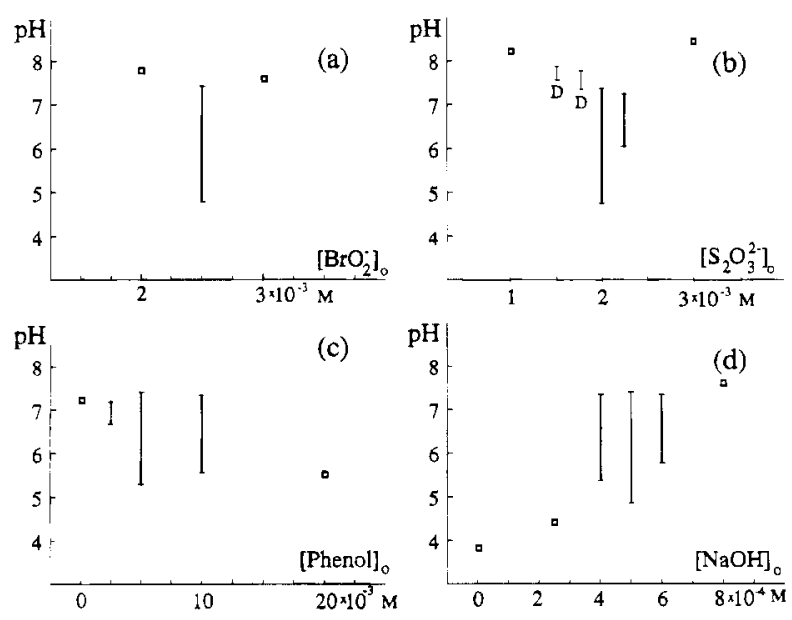

Figure 5. Dependence of the state of the bromite-thiosulfate-phenolsodium hydroxide flow system on input concentrations of the components. In each frame, three of the following four concentrations are fixed while the fourth is varied: $\left[\mathrm{BrO}_{2}^{-}\right]_{0}=2.5 \times 10^{-3} \mathrm{M},\left[\mathrm{S}_{2} \mathrm{O}_{3}{ }^{2-}\right]_{0}$ $=2.0 \times 10^{-3} \mathrm{M},[\text { phenol }]_{0}=5.0 \times 10^{-3} \mathrm{M},[\mathrm{NaOH}]_{0}=5.0 \times 10^{-4}$ M. Flow rate $k_{0}$ is fixed at $8 \times 10^{-4} \mathrm{~s}^{-1}$. Squares and vertical lines indicate steady and oscillatory states, respectively. Length of each vertical line indicates maximum and minimum of $\mathrm{pH}$ oscillations. $\mathrm{D}$ denotes damped oscillations.

and in the potential of a Pt electrode when we increased the concentrations of thiosulfate and phenol in the bistable system described in the previous paragraph. With $\left[\mathrm{BrO}_{2}-\right]_{0}=2.5 \times$ $10^{-3} \mathrm{M},\left[\mathrm{S}_{2} \mathrm{O}_{3}{ }^{2-}\right]_{0}=2 \times 10^{-3} \mathrm{M}$, and [phenol $]_{0}=5 \times 10^{-3}$ $\mathrm{M}$ (the batch behavior of this system is depicted in Figure 3 , curve e), high-amplitude $\left(\mathrm{pH}_{\min }=4.80, \mathrm{pH}_{\max }=7.60\right)$, longperiod ( $30 \mathrm{~min}$ ), sustained oscillations were obtained if dilute $\left(5 \times 10^{-4} \mathrm{M}\right) \mathrm{NaOH}$ was added to the input flow to the reactor. The oscillations appeared in a narrow range of flow rates $\left(k_{0}=\right.$ $7 \times 10^{-4}-1.2 \times 10^{-3} \mathrm{~s}^{-1}$ ). The highest amplitude oscillations, shown in Figure 4, were obtained at $k_{0}=8 \times 10^{-4} \mathrm{~s}^{-1}$.

The amplitude and period of the oscillations were significantly lower $\left(\mathrm{pH}_{\min }=5.7, \mathrm{pH}_{\max }=7.4\right.$, period $\left.11 \mathrm{~min}\right)$ at $k_{0}=1 \times$ $10^{-3} \mathrm{~s}^{-1}$. At still higher $k_{0}$, the $\mathrm{pH}$ oscillations became as small as 0.2 unit. At $k_{0} \leq 5 \times 10^{-4} \mathrm{~s}^{-1}$ and $k_{0}>1.2 \times 10^{-3} \mathrm{~s}^{-1}$, steady $\mathrm{pH}$ values of about 5 and 7.4, respectively, were attained.

Oscillations in the bromite-thiosulfate-phenol-sodium hydroxide flow system occur only in a narrow range of input concentrations. In Figure 5, we summarize the state of the system in the CSTR when one concentration is varied while all the others and the flow rate are held fixed. Oscillations occur only when the ratio $\left[\mathrm{BrO}_{3}{ }^{-}\right]_{0} /\left[\mathrm{S}_{2} \mathrm{O}_{3}{ }^{2-}\right]_{0}$ is within about $10 \%$ of 
$5 / 4$ (Figure 5a and b). The input phenol concentration may be varied by about an order of magnitude without destroying the oscillatory behavior (Figure $5 \mathrm{c}$ ). The system is sensitive to the input $\mathrm{NaOH}$ as well (Figure 5d). Because the bromite solution is alkaline and its $\mathrm{pH}$ decreases on standing (e.g., the $\mathrm{pH}$ of a freshly prepared $2.5 \times 10^{-3} \mathrm{M} \mathrm{NaBrO}_{2}$ changes from 10.2 to 9.0 after $5 \mathrm{~h}$ ), the $[\mathrm{NaOH}]_{0}$ required to maintain oscillations may change if the experiment runs for several hours.

The bromite-thiosulfate-phenol-sodium hydroxide system gives rise to oscillations over a range of concentrations so long as $\left[\mathrm{BrO}_{2}^{-}\right]_{0} /\left[\mathrm{S}_{2} \mathrm{O}_{3}{ }^{2-}\right]_{0}$ is kept close to 1.25 . We have not investigated systems with $\left[\mathrm{BrO}_{2}^{-}\right]_{0}>2.5 \times 10^{-3} \mathrm{M}$. With $\left[\mathrm{BrO}_{2}^{-}\right]_{0}<6.25 \times 10^{-4} \mathrm{M}$, the oscillatory amplitude becomes negligible. Between these two values, however, one need only change $\left[\mathrm{S}_{2} \mathrm{O}_{3}{ }^{2-}\right]_{0}$ and $[\mathrm{phenol}]_{0}$ in proportion to $\left[\mathrm{BrO}_{2}{ }^{-}\right]_{0}$ and adjust $[\mathrm{NaOH}]_{0}$ and the flow rate. For example, the system oscillates when $\left[\mathrm{BrO}_{2}{ }^{-}\right]_{0}=1.25 \times 10^{-3} \mathrm{M},\left[\mathrm{S}_{2} \mathrm{O}_{3}{ }^{2-}\right]_{0}=1 \times$ $10^{-3} \mathrm{M},[\text { phenol }]_{0}=2.5 \times 10^{-3} \mathrm{M},[\mathrm{NaOH}]_{0}=3.75 \times 10^{-4}$ $\mathrm{M}$, and $k_{0}=3 \times 10^{-3} \mathrm{~s}^{-1}$ or when $\left[\mathrm{BrO}_{2}^{-}\right]_{0}=6.25 \times 10^{-4} \mathrm{M}$, $\left[\mathrm{S}_{2} \mathrm{O}_{3}{ }^{2-}\right]_{0}=5 \times 10^{-4} \mathrm{M}$, [phenol $]_{0}=1.25 \times 10^{-3} \mathrm{M},[\mathrm{NaOH}]_{0}$ $=1.9 \times 10^{-4} \mathrm{M}$, and $k_{0}=4 \times 10^{-3} \mathrm{~s}^{-1}$.

In contrast to the oscillatory $\mathrm{BrO}_{2}^{-}-\mathrm{I}^{-4}$ and $\mathrm{BrO}_{2}^{--}$ $\mathrm{NH}_{3} \mathrm{OH}^{+}-$phenol- $\mathrm{NaOH}^{5}$ oscillatory systems, we found no evidence of complex oscillations in the present system.

We introduced a flow of bromide ions under oscillatory conditions to assess the importance of bromide ion inhibition in the bromite-thiosulfate-phenol-sodium hydroxide oscillator. When $\left[\mathrm{BrO}_{2}{ }^{-}\right]_{0}=1.25 \times 10^{-3} \mathrm{M},\left[\mathrm{Br}^{-}\right]_{0}=2.5 \times 10^{-4}$ $\mathrm{M}$ produced negligible effect, while $\left[\mathrm{Br}^{-}\right]_{0}=1 \times 10^{-3} \mathrm{M}$ slowly damped the oscillations. We conclude that bromide ions may play a minor part in this bromite system, but their role in the oscillatory mechanism is much less crucial than in the bromate oscillators.

\section{Discussion}

Lee and Lister ${ }^{13}$ studied the kinetics of the reaction between aqueous bromite and thiosulfate in $10^{-2}-10^{-1} \mathrm{M} \mathrm{NaOH}$ solutions using stopped flow spectrophotometry to monitor the decrease in time of the characteristic bromite peak at $\lambda=296$ $\mathrm{nm}$. They concluded that at least two overall stoichiometries are possible. With a high excess of thiosulfate $\left(\left[\mathrm{S}_{2} \mathrm{O}_{3}{ }^{2-}\right]\right.$ : $\left[\mathrm{BrO}_{2}^{-}\right] \geq 10$ ) and at lower $\left[\mathrm{OH}^{-}\right]$, the system follows the stoichiometry of eq 1 . The rate constant was found to be slightly

$$
\mathrm{BrO}_{2}{ }^{-}+4 \mathrm{~S}_{2} \mathrm{O}_{3}{ }^{2-}+4 \mathrm{H}^{+} \rightarrow \mathrm{Br}^{-}+2 \mathrm{~S}_{4} \mathrm{O}_{6}{ }^{2-}+2 \mathrm{H}_{2} \mathrm{O}
$$

dependent on $\left[\mathrm{OH}^{-}\right]\left(k_{\mathrm{obs}}=k_{1}+k_{2}\left[\mathrm{OH}^{-}\right]^{-1} ; k_{1}=2.39 \mathrm{M}^{-1}\right.$ $\mathrm{s}^{-1}, k_{2}=0.013 \mathrm{~s}^{-1}$ at $T=25^{\circ} \mathrm{C}$ ). Reaction 1 was complete within a few seconds. At this high $\mathrm{pH}$, the tetrathionate formed in eq 1 was assumed to hydrolyze at a measurable rate (firstorder rate constant $0.0083 \mathrm{~s}^{-1}$ ) via reaction 2 .

$$
4 \mathrm{~S}_{4} \mathrm{O}_{6}{ }^{2-}+6 \mathrm{OH}^{-} \rightarrow 5 \mathrm{~S}_{2} \mathrm{O}_{3}{ }^{2-}+2 \mathrm{~S}_{3} \mathrm{O}_{6}{ }^{2-}+3 \mathrm{H}_{2} \mathrm{O}
$$

At lower ratios of thiosulfate to bromite $\left(\left[\mathrm{S}_{2} \mathrm{O}_{3}{ }^{2-}\right]:\left[\mathrm{BrO}_{2}{ }^{-}\right] \leq\right.$ 2.5) and at higher $\left[\mathrm{OH}^{-}\right]$, acid and $\mathrm{SO}_{4}{ }^{2-}$ were produced. The overall stoichiometry for the total oxidation proceeds according to eq 3 .

$$
2 \mathrm{BrO}_{2}^{-}+\mathrm{S}_{2} \mathrm{O}_{3}^{2-}+\mathrm{H}_{2} \mathrm{O} \rightarrow 2 \mathrm{Br}^{-}+2 \mathrm{SO}_{4}{ }^{2-}+2 \mathrm{H}^{+}
$$

No study has been reported of the bromite-thiosulfate reaction at $\mathrm{pH}<12$, but it is reasonable to suppose that the upward and downward jumps in $\mathrm{pH}$ observed in the batch reactions of Figure 1 are a consequence of reactions 1 and 3 . In addition to the overall stoichiometries (1) and (3), a fuller description of the system requires generation of the reactive intermediates $\mathrm{Br}_{2}$ and/or $\mathrm{HOBr}$ formed in eqs 4 and 5 .

$$
\begin{gathered}
2 \mathrm{BrO}_{2}^{-}+6 \mathrm{~S}_{2} \mathrm{O}_{3}{ }^{2-}+4 \mathrm{H}_{2} \mathrm{O} \rightarrow 3 \mathrm{~S}_{4} \mathrm{O}_{6}{ }^{2-}+\mathrm{Br}_{2}+8 \mathrm{OH}^{-} \\
\mathrm{BrO}_{2}{ }^{-}+2 \mathrm{~S}_{2} \mathrm{O}_{3}{ }^{2-}+2 \mathrm{H}_{2} \mathrm{O} \rightarrow \mathrm{S}_{4} \mathrm{O}_{6}{ }^{2-}+\mathrm{HOBr}+3 \mathrm{OH}^{-} \\
\mathrm{Br}_{2}+\mathrm{H}_{2} \mathrm{O} \leftrightarrow \mathrm{HOBr}+\mathrm{Br}^{-}+\mathrm{H}^{+}
\end{gathered}
$$

The intermediates $\mathrm{Br}_{2}$ and $\mathrm{HOBr}$ are known to oxidize $\mathrm{S}_{2} \mathrm{O}_{3}{ }^{2-}$ to $\mathrm{H}_{2} \mathrm{SO}_{4}$ in fast processes (7) and (8).

$$
\begin{aligned}
& \mathrm{S}_{2} \mathrm{O}_{3}{ }^{2-}+4 \mathrm{Br}_{2}+5 \mathrm{H}_{2} \mathrm{O} \rightarrow 2 \mathrm{SO}_{4}{ }^{2-}+8 \mathrm{Br}^{-}+10 \mathrm{H}^{+} \\
& \mathrm{S}_{2} \mathrm{O}_{3}{ }^{2-}+4 \mathrm{HOBr}+\mathrm{H}_{2} \mathrm{O} \rightarrow 2 \mathrm{SO}_{4}{ }^{2-}+4 \mathrm{Br}^{-}+6 \mathrm{H}^{+}
\end{aligned}
$$

In the bromite oscillators described so far, the oscillations occur in the $\mathrm{pH}$ range $4-8$. We have demonstrated earlier that in this $\mathrm{pH}$ range bromite decomposes with the following stoichiometry (for details, see ref 5):

$$
5 \mathrm{BrO}_{2}^{-}+2 \mathrm{H}^{+} \rightarrow 3 \mathrm{BrO}_{3}^{-}+\mathrm{Br}_{2}+\mathrm{H}_{2} \mathrm{O}
$$

Reaction 9 is slow at $\mathrm{pH} \leq 7$ and speeds up significantly at lower $\mathrm{pH}$. It is complete within minutes at $\mathrm{pH} 4-5$. Reaction 9 is likely to be important in the bromite-thiosulfate-phenol oscillatory reaction for at least three reasons: (i) it is initiated by acid but consumes acid, resulting in a $\mathrm{pH}$ rise in acidic solution; (ii) at lower $\mathrm{pH}$ values, the bromite may partially or completely be removed from the system by eq 9 ; (iii) the bromine formed in reaction 9 oxidizes thiosulfate and brominates phenol faster than does bromite, which makes process 9 a plausible initiation step for the bromite-thiosulfate and bromite-phenol reactions.

The reaction between bromite and thiosulfate is oscillatory only if phenol is present. The phenol can react with $\mathrm{BrO}_{2}{ }^{-}$, $\mathrm{Br}_{2}$, or $\mathrm{HOBr}$. Reaction between $\mathrm{BrO}_{2}^{-}$and phenol probably occurs via process 9 , resulting in the stoichiometry

$$
\begin{array}{r}
5 \mathrm{BrO}_{2}{ }^{-}+\mathrm{C}_{6} \mathrm{H}_{5} \mathrm{OH}+\mathrm{H}^{+} \rightarrow 3 \mathrm{BrO}_{3}^{-}+\mathrm{Br}^{-}+ \\
\mathrm{BrC}_{6} \mathrm{H}_{4} \mathrm{OH}+\mathrm{H}_{2} \mathrm{O}
\end{array}
$$

The reaction between phenol and bromine in aqueous solution is diffusion controlled above $\mathrm{pH}$ 4.5. ${ }^{14}$ Also, $\mathrm{HOBr}$ reacts rapidly with phenols, acting as a brominating rather than as an oxidizing species. ${ }^{15}$

The shapes of the batch curves, the bistability, and the oscillations can be qualitatively explained with the aid of reactions $1-10$. In curve a of Figure 1 , the $\mathrm{pH}$ drop to 4 and the rise to about 5.8 result from the total oxidation of $\mathrm{S}_{2} \mathrm{O}_{3}{ }^{2-}$ by the excess $\mathrm{BrO}_{2}{ }^{-}$in reaction 3 followed by the decomposition of the unreacted $\mathrm{BrO}_{2}{ }^{-}$in step 9. At the reagent concentrations where curves $b, c$, and $d$ of Figure 1 were recorded, the rapid $\mathrm{H}^{+}$-consuming reaction (1) precedes the $\mathrm{H}^{+}$-producing reaction (3). Curves $e$ and $f$ of Figure 1 were measured in excess thiosulfate where reaction 1 predominates. The resultant high $\mathrm{pH}$ allows the hydrolysis reaction (2) to proceed, causing a slow decrease in $\mathrm{pH}$. The curves in Figure 3 suggest that eq 1, the direct reaction between $\mathrm{BrO}_{2}{ }^{-}$and $\mathrm{S}_{2} \mathrm{O}_{3}{ }^{2-}$, is not influenced by the addition of phenol. However, the second section of the curves is markedly modified in the presence of phenol, implying a strong inhibition of reaction 3 by that species. This inhibitory effect arises from the competition between phenol and thiosulfate for the intermediates $\mathrm{Br}_{2}$ and/or $\mathrm{HOBr}$. We suggest that the acid production associated with the overall process (3) results from the reaction between $\mathrm{Br}_{2}$ and/or $\mathrm{HOBr}$ and $\mathrm{S}_{2} \mathrm{O}_{3}{ }^{2-}$ according to eqs 7 and 8 . The fast reaction between these 
intermediates and the phenol competes with eqs 7 and 8 , leading to the delay, or even the total suppression, of reaction 3 in the presence of phenol.

The bromite-thiosulfate reaction has only one steady state in a CSTR. The $\mathrm{pH}$ of this steady state is established by the two consecutive fast reactions (1) and (3). Addition of phenol slows reaction 3 and separates it in time from the unaffected reaction (1). This time separation and the autocatalysis in reaction 3 result in the existence of two stable steady states in the bromite-thiosulfate-phenol flow system. Because reaction 1 is faster than reaction 3 , high flow rates lead to a high $\mathrm{pH}$ steady state. Decreasing the flow rate, i.e., increasing the residence time in the reactor, allows the overall reaction to proceed to a greater extent, and transition from SSI to SSII occurs. In SSII, the final $\mathrm{pH}$ is primarily determined by reaction 3. In the bistable region, where both SSI and SSII are stable, all reactions from (1) to $(10)$ can play a role in the CSTR dynamics.

Because no elementary step mechanism for the composite reactions $(1)-(10)$ is known, it is not obvious which part of the bromite-thiosulfate system should be identified with the autocatalysis. One may regard $\mathrm{HOBr}$ as the autocatalytic species, in analogy with the oscillatory bromite-iodide reaction, ${ }^{16}$ but it may be more appropriate to consider autocatalysis by hydrogen ions. For example, if the acid production in the overall process (3) occurs through the intermediates $\mathrm{Br}_{2}$ and/or $\mathrm{HOBr}$ formed in eqs 4 and/or 5 , the $\mathrm{H}^{+}$produced in reactions 7 and/or 8 accelerates the decomposition of bromite in eq 9 . The additional bromine leads to more $\mathrm{H}^{+}$, providing an autocatalytic $\mathrm{pH}$ decrease.

At this point, we can only speculate how the oscillations in the bromite-thiosulfate-phenol-sodium hydroxide flow system arise. Consider a typical oscillatory $\mathrm{pH}$ curve such as that of Figure 4a. At an intermediate $\mathrm{pH}$ value, the $\mathrm{pH}$ can either increase or decrease, depending on the other concentrations in the system or, equivalently, on the direction from which this $\mathrm{pH}$ is approached. If thiosulfate is temporarily in stoichiometric excess, the $\mathrm{pH}$ will rise and the ratio of bromite to thiosulfate will shift in favor of bromite owing to the predominance of reaction 1. At high $\mathrm{pH}$ and high bromite, the overall stoichiometry will switch from reaction 1 to reaction 3 . The $\mathrm{pH}$ now decreases, which continues until nearly all the thiosulfate is consumed. At the $\mathrm{pH}$ minimum, the remaining unreacted bromite decomposes via eq 9 , resulting in a $\mathrm{pH}$ rise. The bromine evolved in reaction 9 is immediately scavenged by the phenol. Now the reactor is practically free from the reactive species bromite, thiosulfate, and bromine. Restoration of the initial $\mathrm{pH}$ is assisted by the $\mathrm{NaOH}$ input. During the replenishment of the reagents by the flow, the slow reaction between bromite and phenol may delay the buildup of bromite, allowing the establishment of the stoichiometric excess of thiosulfate to bromite necessary to restart the cycle.

Thiosulfate participates in many oscillatory reactions. The driving force in these oscillatory mechanisms is generally attributed solely to the oxidants, but thiosulfate can also play rather different roles in the individual systems. The following oxidant-thiosulfate reactions have been shown to behave in an oscillatory manner: $\mathrm{H}_{2} \mathrm{O}_{2}-\mathrm{S}_{2} \mathrm{O}_{3}{ }^{2-}-\mathrm{Cu}$ (II) catalyst, ${ }^{17} \mathrm{IO}_{3}{ }^{-}-$ $\mathrm{S}_{2} \mathrm{O}_{3}{ }^{2-}-\mathrm{HSO}_{3}{ }^{-18} \mathrm{IO}_{4}{ }^{-}-\mathrm{S}_{2} \mathrm{O}_{3}{ }^{2-},{ }^{19} \mathrm{ClO}_{2}{ }^{-}-\mathrm{S}_{2} \mathrm{O}_{3}{ }^{2-},{ }^{20} \mathrm{~S}_{2} \mathrm{O}_{8}{ }^{2-}$ $\mathrm{S}_{2} \mathrm{O}_{3}{ }^{2-},{ }^{21} \mathrm{MnO}_{4}{ }^{-}-\mathrm{S}_{2} \mathrm{O}_{3}{ }^{2-}-\left(\right.$ stabilizer $\mathrm{PO}_{4}{ }^{3-}$ or $\left.\mathrm{AsO}_{4}{ }^{3-}\right),{ }^{22}$ and $\mathrm{BrO}_{2}{ }^{-}-\mathrm{S}_{2} \mathrm{O}_{3}{ }^{2-}-$ phenol. It is interesting to consider the role of thiosulfate in the above systems. The oscillators containing $\mathrm{H}_{2} \mathrm{O}_{2}, \mathrm{IO}_{3}{ }^{-}$, and $\mathrm{IO}_{4}{ }^{-}$represent typical $\mathrm{pH}$ oscillators. In all of these, the $\mathrm{H}^{+}$consumption reaction involves the partial oxidation of $\mathrm{S}_{2} \mathrm{O}_{3}{ }^{2-}$ to $\mathrm{S}_{4} \mathrm{O}_{6}{ }^{2-}$, and the $\mathrm{H}^{+}$-producing process is the total oxidation of $\mathrm{S}_{2} \mathrm{O}_{3}{ }^{2-}$ to $\mathrm{SO}_{4}{ }^{2-}$ (in the single-substrate systems) or the oxidation of a second substrate, $\mathrm{HSO}_{3}{ }^{-}$(in the mixed-substrate $\mathrm{pH}$ oscillators). The $\mathrm{ClO}_{2}{ }^{-}-\mathrm{S}_{2} \mathrm{O}_{3}{ }^{2-}$ flow system oscillates in buffer, indicating a completely different mechanism. Here the oscillations are related to the autocatalytic $\mathrm{HOCl}$ production assisted by $\mathrm{S}_{2} \mathrm{O}_{3}{ }^{2-}$ and to the removal of $\mathrm{HOCl}$ by its direct reaction with $\mathrm{S}_{2} \mathrm{O}_{3}{ }^{2-}$. The $\mathrm{S}_{2} \mathrm{O}_{8}{ }^{2-}-\mathrm{S}_{2} \mathrm{O}_{3}{ }^{2-}-$ $\mathrm{Cu}(\mathrm{II})$ system is believed to oscillate through a radical mechanism in which thiosulfate radicals $\mathrm{S}_{2} \mathrm{O}_{3}{ }^{\circ-}$ play a decisive role. Oscillations in the $\mathrm{MnO}_{4}{ }^{-}-\mathrm{S}_{2} \mathrm{O}_{3}{ }^{2-}-\mathrm{PO}_{4}{ }^{3-}$ reaction proceed through a totally distinct route. Like the substrates in other permanganate oscillators, the thiosulfate acts merely as a simple reductant that generates a soluble $\mathrm{Mn}(\mathrm{IV})$ compound from $\mathrm{MnO}_{4}{ }^{-}$. The autocatalysis and the removal of the autocatalyst are not related to the thiosulfate.

The $\mathrm{BrO}_{2}{ }^{-}-\mathrm{S}_{2} \mathrm{O}_{3}{ }^{2-}-$ phenol oscillator can be regarded as $\mathrm{pH}$ driven, at least under conditions where the change in the $\mathrm{pH}$ is large. However, in the small-amplitude $\mathrm{pH}$ oscillations $(\Delta \mathrm{pH}$ $<0.2-0.3$ unit), a limit cycle involving $\mathrm{HOBr}$ autocatalysis-by analogy to the $\mathrm{ClO}_{2}{ }^{-}-\mathrm{S}_{2} \mathrm{O}_{3}{ }^{2-}$ system-may also be a possibility.

Our study of the bromite-thiosulfate-phenol system, while it still leaves many open questions, sheds important new light on the chemistry of the bromite ion. In particular, it is clear that bromite oscillators function by very different routes from the apparently similar chlorite or bromate oscillators. Nevertheless, our growing knowledge of the chemistry of $\mathrm{BrO}_{2}^{-}$and the related species $\mathrm{HBrO}_{2}$ should prove useful in the continuing effort to clarify the mechanism of the prototype BelousovZhabotinsky reaction.

Acknowledgment. This work was supported by the National Science Foundation (CHE-9023294), by the Hungarian Academy of Sciences (OTKA I/3 No. 2275 to M.O.), and by a U.S.Hungarian copperative grant (INT-8921816). We thank Kenneth Kustin for helpful discussions and a critical reading of the manuscript.

\section{References and Notes}

(1) Part 91 in the series "Systematic Design of Chemical Oscillators". Part 90: He, X.; Kustin, K.; Nagypál, I.; Peintler, G. Inorg. Chem. 1994, $33,2077$.

(2) L. Eötvös University.

(3) Brandeis University.

(4) Orbán, M.; Epstein, I. R. J. Am. Chem. Soc. 1992, 114, 1252.

(5) Orbán, M.; Epstein, I. R. J. Phys. Chem. 1994, 98, 2930. 93.

(6) Massagli, A.; Indelli, A.; Pergola, I. Inorg. Chim. Acta 1970, 4,

(7) Lister, M. V.; McLeod, P. F. Can. J. Chem. 1971, 49, 1987

(8) However, at $\mathrm{pH} \leq 0$, the bromate-phenol reaction can oscillate in a closed system. See: Orbán, M.; Körös, E. J. Phys. Chem. 1978, 82. 1672.

(9) Sorum, C. H.; Charlton, F. S.; Neptune. J. A.; Edwards, J. C. J. Am. Chem. Soc. 1952, 74, 219.

(10) Sadtler Standard UV Spectra; Sadtler Research Laboratories: Philadelphia. 1966; Vol. 1, No. 285.

(11) Lee, C. L.; Lister, M. V. Can. J. Chem. 1971, 49, 2822

(12) Sadtler Standard UV Spectra; Sadtler Research Laboratories: Philadelphia. 1966; Vol, 6, No. 1365.

(13) Lee, C. L.; Lister, M. V. Can. J. Chem. 1979, 57, 1524

(14) Tee, O. S.; Iyengar, N. R.; Parenti, M. J. Org. Chem. 1983, 48, 759.

(15) Györgyi, L.; Varga, M.; Körös, E.; Field, R. J.; Ruoff, P. J. Phys. Chem. 1989, 93, 2836.

(16) Faria. R. B.; Lengyel, I.; Epstein, I. R.; Kustin. K. J. Phys. Chem. 1993, 97,1164

(17) Orbán, M.; Epstein, I. R. J. Am. Chem. Soc. 1987, 109, 101

(18) Rábai, Gy.; Beck. M. T. J. Phys. Chem. 1988, 92, 2804.

(19) Rábai, Gy.; Beck, M. T.: Kustin, K.; Epstein, I. R. J. Phy.s. Chem. $1989,93,2853$

(20) Orbán, M.; De Kepper. P.; Epstein, I. R. J. Phys. Chem. 1982, 86, 431.

(21) Orbán, M.; Epstein, I. R. J. Am. Chem. Soc. 1989, 111, 2891

(22) Orbán, M.; Epstein, I. R. J. Am. Chem. Soc. 1990, 112, 1812.

JP942752J 